\title{
Invasive mosquito species Aedes albopictus and Aedes aegypti on the Black Sea coast of the Caucasus: genetics (COI, ITS2), Wolbachia and Dirofilaria infections
}

\author{
E.V. Shaikevich ${ }^{1} \otimes$, I.V. Patraman², A.S. Bogacheva ${ }^{3}$, V.M. Rakova ${ }^{2}$, O.P. Zelya ${ }^{2}$, L.A. Ganushkina ${ }^{2}$ \\ ${ }^{1}$ Vavilov Institute of General Genetics, RAS, Moscow, Russia \\ ${ }^{2}$ Institute of Medical Parasitology and Tropical Medicine named after E. Martsinovskii, Sechenov First Moscow State Medical University, Moscow, Russia \\ ${ }^{3}$ Moscow State University, Moscow, Russia
}

The area of invasive species Aedes albopictus and Aedes aegypti is expanding. Precise identification and understanding of the genetic diversity of invasive mosquito populations allows us to develop appropriate control methods. Endosymbiotic bacterium Wolbachia pipientis has different effects on their arthropod hosts and can influence the transmission and spread of the pathogens. The objective of the presented study was molecular-genetic identification of the Aedes mosquitoes collected in sampling sites on the Black Sea coast from 2007 to 2017; determination of genetic variability of Ae. aegypti, Ae. albopictus and their symbiotic bacteria Wolbachia; assessment of mosquitoes ability to be infected and to spread parasitic Dirofilaria. Another objective was obtaining the genetic characteristic of laboratory strain Ae. aegypti IMPITM. We investigated two markers of nuclear and mitochondrial DNA from Ae. albopictus and Ae. aegypti and compared them to DNA from Ae. cretinus and Ae. koreicus sympatrically inhabiting the territory, as well as to one of Ae. aegypti from a laboratory line. The study of nuclear and mitochondrial DNA revealed a low level of variability in the invasive mosquitoes Ae. albopictus and Ae. aegypti collected at different collection sites and in different years. More than a half of Ae. albopictus were infected with Wolbachia, two strains of bacteria, wAlbA and wAlbB, occur in the Ae. albopictus population on the Black Sea coast. Total infection of Ae. aegypti and Ae. albopictus with dirofilariae was $1.8 \%$. Dirofilaria immitis was found only in mosquito abdomen, larvae of infective stage L3 were not found. D. repens larvae developed to the infective stage in the mosquitoes of both species.

Key words: blood-sucking mosquitoes; Aedes aegypti; Aedes albopictus; invasion; population; Black Sea coast; ITS2; COl; Wolbachia; Dirofilaria.

\section{Инвазивные виды Aedes albopictus и Aedes aegypti на Черноморском побережье Краснодарского края: генетика (COI, ITS2), зараженность Wolbachia и Dirofilaria}

\author{
Е.В. Шайкевич ${ }^{1}$ 囚, И.В. Патраман ${ }^{2}$, А.С. Богачева ${ }^{3}$,

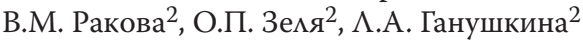 \\ ${ }^{1}$ Институт общей генетики им. Н.И. Вавилова РАН, Москва, Россия \\ ${ }^{2}$ Институт медицинской паразитологии, тропических и трансмиссивных \\ заболеваний им. Е.И. Марциновского Первого Московского \\ государственного медицинского университета им. И.М. Сеченова \\ (Сеченовский университет) Министерства здравоохранения РФ, \\ Москва, Россия \\ ${ }^{3}$ Московский государственный университет им. М.В. Ломоносова, \\ Москва, Россия
}

Ареал инвазивных видов Aedes aegypti и Aedes albopictus, переносчиков ряда трансмиссивных инфекций, расширяется. Идентификация видов-переносчиков и понимание генетического разнообразия инвазивных популяций позволяют разработать соответствующие профилактические мероприятия. Эндосимбиотическая бактерия Wolbachia pipientis оказывает различные эффекты на своих хозяев-артропод и может влиять на процесс передачи и распространения возбудителей. Основной целью работы была молекулярно-генетическая идентификация видов комаров рода Aedes, собранных в населенных пунктах Черноморского побережья с 2007 по 2017 г.; определение генетической изменчивости Ae. aegypti, Ae. albopictus и их симбиотической бактерии Wolbachia; оценка способности Ae. aegypti и Ae. albopictus к заражению и распространению паразитических Dirofilaria. Отдельной задачей являлась генетическая характеристика лабораторной линии Ae. aegypti ИМПиТМ, которая поддерживается в лаборатории в течение 50 лет. Исследованы маркеры ядерной и митохондриальной ДНК у Ae. albopictus и Ae. aegypti и проведено их сравнение с Ae. cretinus и Ae. koreicus, симпатрически обитающими на данной территории, а также с Ae. aegypti лабораторной линии. Обнаружен низкий уровень изменчивости Ae. albopictus и Ae. aegypti, собранных в природе в разных точках сбора и в разное время. У Ae. albopictus выявлены четыре гаплотипа на основе сравнения вариабельной области внутреннего транскрибируемого спейсера (ITS2) кластера генов рPHК и два митохондриальных гаплотипа при сравнении последователь- 
ностей гена первой субъединицы цитохромоксидазы (COI). у Ae. aegypti, собранных в природе, обнаружены четыре гаплотипа ядерной ДНК и три митохондриальных гаплотипа. Более половины Ae. albopictus заражены Wolbachia. В популяции на Черноморском побережье Краснодарского края встречаются два штамма бактерии: wAlbA и wAlbB. Общая зараженность комаров Ae. aegypti и Ae. albopictus дирофиляриями составила $1.8 \%$. Dirofilaria immitis обнаружены только в брюшках комаров, развития личинок до инфекционной стадии L3 не выявлено. Личинки D. repens развились до инфекционной стадии в комарах обоих видов.

Ключевые слова: кровососущие комары; Aedes aegypti; Aedes albopictus; инвазия; популяция; Черноморское побережье Кавказа; ITS2; COl; Wolbachia; Dirofilaria.

HOW TO CITE THIS ARTICLE:

Shaikevich E.V., Patraman I.V., Bogacheva A.S., Rakova V.M ., Zelya O.P., Ganushkina L.A. Invasive mosquito species Aedes albopictus and Aedes aegypti on the Black Sea coast of the Caucasus: genetics (COI, ITS2), infection with Wolbachia and Dirofilaria. Vavilovskii Zhurnal Genetiki i Selektsii = Vavilov Journal of Genetics and Breeding. 2018;22(5):574-585. DOI 10.18699/VJ18.397

A $\mathrm{t}$ the beggining of the 21 st century, expansion of two mosquito species - Aedes (Stegomiya) aegypti (Linnaeus, 1796) and Aedes (Stegomiya) albopictus (Skuse, 1895) - was registered in Krasnodarskiy Region. These are associated with numerous epidemic outbreaks of denge, chikungunya, zika viral infections, etc. Ae. aegypti also acts as a primary carrier for yellow fever (Jeffries, Walker, 2016). Beside arboviruses, both mosquito species are able to transmit the threadworm larvae of Dirofilaria family responsible for dirofilariasis in humans and animals (Ganushkina et al., 2014a). This transmissible helmintosis demonstrates an expansive trend in the territory of Russia (Bogacheva et al., 2017).

Ae. aegypti had been absent in Russia for 50 years, until 2001 (Ryabova et al., 2005; Yunicheva et al., 2008) due to the special measures taken in the USSR in the 1920s and 1930s aimed at eradication of the aforementioned species (Martsinovsky, 1929). The measures were taken considering the extreme danger of this carrier and occurrence of substantial high-mortality dengue outbreaks in the countries of South Europe.

Later in the 20th century, greater concerns aroused worldwide about the expansion of Ae. albopictus, another effective carrier of dangerous arboviruses, which started to spread beyond its natural habitat in Southeast Asia. This mosquito species expanded into areas, previously inhabited by other endemic species, like morphologically similar Ae. cretinus Edwards (Patsoula et al., 2006). For the first time, this species was transferred to Albania from China in the middle of the 1970s (Adhami, Reiter, 1998). Currently this species of mosquito is found in more than 15 countries, and its habitat is growing persistently (Medlock et al., 2015). Ae. albopictus are able to cause outbreaks of dengue and chicagunya infections even in absence of Ae. aegypti (Delatte et al., 2008; Delisle et al., 2015; Calba et al., 2017; Chuchuy et al., 2018). In the Russian Federation these species were first found in 2011 (Ganushkina et al., 2012). Currently, the Caucasus coast of the Black Sea is the only territory in the WHO European region that geographically includes the Asian region of the Caucasus where the both mosquito species have been registered as active vectors for arbovirus infectious agents (http://www. who.int/about/regions/euro/).

Hematophagous mosquito species may vary in pathogen transmission capability. Their morphological markers used for authentication could be either unclear, or missed or erased during storage of adult specimens, which results in identification errors. For example, cytochrome gene sequence MF148262 annotated in Gene Bank as being derived from Ae. albopictus originated in Malaysia, was actually associated with Ae. aegypti. For that reason, DNA analysis for verification of the population's structure and diversity had to be performed to devise necessary preventive measures.

Dirofilariasis caused by Dirofilaria immitis and $D$. repens is endemic to the Southern parts of Russia (Sergiev et al., 2014; Kartashev et al., 2018). In assessment of epidemiological situation one uses xenomonitoring for entomological control over filariasis infections (Ganushkina et al., 2014a). Dirofilaries are identified by means of total DNA amplification of vector mosquito with specific primers. This method shows fillaries at all stages of development (L1, L2, L3), while not every filaria reaches the pathogenic L3 stage, which can be transmitted through salivary glands of a mosquito to human and animal hosts. Microfilaria development to stage L3 requires certain thermal conditions, therefore the disease is primarily limited to southern regions. Dirofilaria can be found in mosquitoes of the following genera: Aedes, Anopheles, Ochlerotatus and Culex (Bochková et al., 2013; Kronefeld et al., 2014; Bogacheva et al., 2017). During monitoring, taxonomical study of mosquitoes can be frequently limited to the genus level. Dirofilaria identification, specialization towards mosquito species and determining the invasive stage of Dirofilaria inside the mosquito are aimed towards discovering the actual epidemiological significance of various mosquito species (Ganushkina et al., 2014a). Major attention in latest research has been paid to discovering the role of endosymbiotic bacteria in the mosquito and other arthropods in the host survivability, as well as in processes of transmission 
and spread of infectious diseases (Bourtzis et al., 2014; Jeffries, Walker, 2016).

The main objectives of the presented research were molecular genetics identification of Ae. albopictus and Ae. aegypti collected in the populated areas of the Black Sea coast from 2007 to 2017; determination of their gene diversity; characterization of sympatric species Ae. cretinus and Ae. koreicus; measuring of symbiotic bacteria Wolbachia appearence in investigated mosquito samples and of Wolbachia strains diversity within the population of Ae. albopictus; evaluation of the capability of Ae. albopictus and Ae. aegypti to vector and spread parasitic Dirofilaria. Within the framework of the study one also performed genetic sampling of the laboratory line of Ae. aegypti IMPITM cultivated for 50 years.

\section{Materials and methods}

Collecting the mosquitoes. The mosquitoes were collected on the North Caucasus shore in years 2007, 2011-2013 and 2015-2017 (Table 1, Fig. 1).Ae. albopictus and Ae. aegypti larvae were picked in temporal water basins using a scoopnet. A part of the larvae was preserved in alcohol, while the others were raised to adults. The adult mosquitoes were caught either with an Electrofrog trap (LMD-Komplekt plus, Russia), or "on self" with an exhauster and preserved dry. More details on the mosquito collection protocol can be found in (Ganushkina et al., 2013, 2016). The total collection consisted of 3005 specimens: 1430 Ae. aegypti and 1575 Ae. albopictus.

Molecular genetic analysis included mosquitoes from the IMPITM lab line, four dried adult Ae. cretinus from the IMPITM museum and five Ae. koreicus collected in Sochi in 2013. The Ae. cretinus and Ae. koreicus were used to determine the genetic differences between morphologically similar species of the Aedes genus, which could potentially present in the collections, collected in the territory in question. Ae. cretinus is endemic towards the Black Sea coast of the Caucasus. Ae. koreicus originating from Southeast Asia, have been found in the area since 2013 (Ganushkina et al., 2016).

Determining species of mosquitoes. Species identification of all the mosquito samples was conducted with account for the morphology data (Gutsevich et al., 1970) and using molecular genetic technologies. Up to 30 specimens from each place and year were used for PCR identification of second inner transcribable spacer of pRNA gene cluster (ITS2). Characteristic to Ae. albopictus is PCR sequence of $500 \mathrm{bp}$ in size, for Ae. koreicus - $450 \mathrm{bp}$, for Ae. cretinus $390 \mathrm{bp}$, and for Ae. aegypti - $340 \mathrm{bp}$.

Mosquito identification by gene sampling. DNA extraction from the mosquitoes was accomplished using DIAtom DNA Prep (Izogen, Moscow). PCR identification was conducted with the Evrogen Encyclo PCR kit (Evrogen, Moscow). For the ITS2 amplification primers 5,8S and 28S were used (Porter, Collins, 1991). A cytochrom oxidase I sequence $(\mathrm{COI})$ of nearly $750 \mathrm{bp}$ in length was built up using primers TY-J-1460 (Simon et al., 1994) and COIR (Shaikevich, 2007). Amplificates
Table 1. Years and points of Ae. aegypti and Ae. albopictus sampling

\begin{tabular}{|c|c|c|c|c|}
\hline \multirow[t]{2}{*}{ Year } & \multirow[t]{2}{*}{ Sampling site } & \multirow{2}{*}{$\begin{array}{l}\text { Geographical } \\
\text { coordinates }\end{array}$} & \multicolumn{2}{|c|}{ Number of individuals } \\
\hline & & & Ae. aegypti & Ae. albopictus \\
\hline \multirow[t]{4}{*}{2007} & Adler & $\begin{array}{l}43^{\circ} 25^{\prime} 44^{\prime \prime} \mathrm{N} \\
39^{\circ} 55^{\prime} 26^{\prime \prime} \mathrm{E}\end{array}$ & 52 & 0 \\
\hline & Sochi & $\begin{array}{l}43^{\circ} 35^{\prime} 07^{\prime \prime} \mathrm{N} \\
39^{\circ} 43^{\prime} 13^{\prime \prime} \mathrm{E}\end{array}$ & 89 & 0 \\
\hline & Lazarevskoye & $\begin{array}{l}43^{\circ} 54^{\prime} 31^{\prime \prime} \mathrm{N} \\
39^{\circ} 19^{\prime} 52^{\prime \prime} \mathrm{E}\end{array}$ & 25 & 0 \\
\hline & Tuapse & $\begin{array}{l}44^{\circ} 06^{\prime} 19^{\prime \prime} \mathrm{N} \\
39^{\circ} 04^{\prime} 48^{\prime \prime} \mathrm{E}\end{array}$ & 23 & 0 \\
\hline 2011 & Hosta & $\begin{array}{l}43^{\circ} 30^{\prime} 53^{\prime \prime} \mathrm{N} \\
39^{\circ} 52^{\prime} 05^{\prime \prime} \mathrm{E}\end{array}$ & 1 & 16 \\
\hline \multirow[t]{9}{*}{2012} & Adler & $\begin{array}{l}43^{\circ} 25^{\prime} 44^{\prime \prime} \mathrm{N} \\
39^{\circ} 55^{\prime} 26^{\prime \prime} \mathrm{E}\end{array}$ & 3 & 24 \\
\hline & Hosta & $\begin{array}{l}43^{\circ} 30^{\prime} 53^{\prime \prime} \mathrm{N} \\
39^{\circ} 52^{\prime} 05^{\prime \prime} \mathrm{E}\end{array}$ & 0 & 47 \\
\hline & Sochi & $\begin{array}{l}43^{\circ} 35^{\prime} 07^{\prime \prime} \mathrm{N} \\
39^{\circ} 43^{\prime} 13^{\prime \prime} \mathrm{E}\end{array}$ & 6 & 116 \\
\hline & Mamaika & $\begin{array}{l}43^{\circ} 38^{\prime} 35^{\prime \prime} \mathrm{N} \\
39^{\circ} 42^{\prime} 34^{\prime \prime} \mathrm{E}\end{array}$ & 48 & 406 \\
\hline & Dagomys & $\begin{array}{l}43^{\circ} 40^{\prime} 11^{\prime \prime} \mathrm{N} \\
39^{\circ} 40^{\prime} 07^{\prime \prime} \mathrm{E}\end{array}$ & 0 & 24 \\
\hline & Lazarevskoye & $\begin{array}{l}43^{\circ} 54^{\prime} 31^{\prime \prime} \mathrm{N} \\
39^{\circ} 19^{\prime} 52^{\prime \prime} \mathrm{E}\end{array}$ & 31 & 48 \\
\hline & Tuapse & $\begin{array}{l}44^{\circ} 06^{\prime} 19^{\prime \prime} \mathrm{N} \\
39^{\circ} 04^{\prime} 48^{\prime \prime} \mathrm{E}\end{array}$ & 566 & 28 \\
\hline & New Afon & $\begin{array}{l}43^{\circ} 04^{\prime} 50^{\prime \prime} \mathrm{N} \\
40^{\circ} 50^{\prime} 17^{\prime \prime} \mathrm{E}\end{array}$ & 45 & 6 \\
\hline & Pizunda & $\begin{array}{l}43^{\circ} 09^{\prime} 43^{\prime \prime} \mathrm{N} \\
40^{\circ} 20^{\prime} 27^{\prime \prime} \mathrm{E}\end{array}$ & 7 & 58 \\
\hline \multirow[t]{6}{*}{2013} & Adler & $\begin{array}{l}43^{\circ} 25^{\prime} 44^{\prime \prime} \mathrm{N} \\
39^{\circ} 55^{\prime} 26^{\prime \prime} \mathrm{E}\end{array}$ & 6 & 164 \\
\hline & Hosta & $\begin{array}{l}43^{\circ} 30^{\prime} 53^{\prime \prime} \mathrm{N} \\
39^{\circ} 52^{\prime} 05^{\prime \prime} \mathrm{E}\end{array}$ & 0 & 23 \\
\hline & Sochi & $\begin{array}{l}43^{\circ} 35^{\prime} 07^{\prime \prime} \mathrm{N} \\
39^{\circ} 43^{\prime} 13^{\prime \prime} \mathrm{E}\end{array}$ & 3 & 46 \\
\hline & Mamaika & $\begin{array}{l}43^{\circ} 38^{\prime} 35^{\prime \prime} \mathrm{N} \\
39^{\circ} 42^{\prime} 34^{\prime \prime} \mathrm{E}\end{array}$ & 3 & 34 \\
\hline & Lazarevskoye & $\begin{array}{l}43^{\circ} 54^{\prime} 31^{\prime \prime} \mathrm{N} \\
39^{\circ} 19^{\prime} 52^{\prime \prime} \mathrm{E}\end{array}$ & 17 & 19 \\
\hline & Tuapse & $\begin{array}{l}44^{\circ} 06^{\prime} 19^{\prime \prime} \mathrm{N} \\
39^{\circ} 04^{\prime} 48^{\prime \prime} \mathrm{E}\end{array}$ & 394 & 21 \\
\hline \multirow[t]{2}{*}{2015} & Adler & $\begin{array}{l}43^{\circ} 25^{\prime} 44^{\prime \prime} \mathrm{N} \\
39^{\circ} 55^{\prime} 26^{\prime \prime} \mathrm{E}\end{array}$ & 0 & 120 \\
\hline & Tuapse & $\begin{array}{l}44^{\circ} 06^{\prime} 19^{\prime \prime} \mathrm{N} \\
39^{\circ} 04^{\prime} 48^{\prime \prime} \mathrm{E}\end{array}$ & 30 & 20 \\
\hline 2016 & Dagomys & $\begin{array}{l}43^{\circ} 40^{\prime} 11^{\prime \prime} \mathrm{N} \\
39^{\circ} 40^{\prime} 07^{\prime \prime} \mathrm{E}\end{array}$ & 0 & 256 \\
\hline 2017 & Adler & $\begin{array}{l}43^{\circ} 25^{\prime} 44^{\prime \prime} \mathrm{N} \\
39^{\circ} 55^{\prime} 26^{\prime \prime} \mathrm{E}\end{array}$ & 81 & 32 \\
\hline & Sochi & $\begin{array}{l}43^{\circ} 35^{\prime} 07^{\prime \prime} \mathrm{N} \\
39^{\circ} 43^{\prime} 13^{\prime \prime} \mathrm{E}\end{array}$ & 0 & 67 \\
\hline & Total & & 1430 & 1575 \\
\hline
\end{tabular}


were visualized in 1-2 \% agarous gel and purified using a clean-up extraction kit (Evrogen, Moscow) followed by sequencing with the BigDye Termination kit 3.1 (Applied Biosystems, USA). Thirteen ITS2 amplificates of Ae. aegypti и Ae. albopictus were sequenced (1-2 samples from 10 collection sites for various years), including Ae. cretinus and Ae. aegypti taken in the amount of one sample from each line. Mitochondrial DNA variability was studied using 28 sequenced sequences of the COI gene, $634 \mathrm{bp}$ in length, from 1-4 specimens collected at 1-4 sites and four specimens from the Ae. aegypti lab line. The sequences were registered in Gene Bank. The COI gene: Ae. aegypti MG198586-MG198594, MH251909-MH251911; Ae. albopictus MG198595-MG198606; Ae. aegypti IMPITM MH023409 и ITS2: Ae. aegypti MH142316-MH142320; Ae. albopictus MH142321-MH142326; Ae. aegypti IMPITM MH142327; Ae. cretinus MH142328.

Data analysis. Gene sequence analysis was performed using the following software: ChromasPro, BLASTN, ClustalW, MAFFT v.6, MEGA v.6. Phylogenetic trees were built using the Neighbor-Joining technique, the evolution distances were calculated by maximum composite likelihood method using MEGA v.6 program (Tamura et al., 2013). The DNA sequences of Ae. albopictus and $A e$. aegypti closest to the extracted ones, as well as ones characteristic for certain regions were selected in Gene Bank (https://www.ncbi.nlm.nih.gov/) for the purpose of comparative analysis. Their registry numbers can be found on the diagrams. Sample collection time periods are indicated in the annotations, where it is possible. The statistical reliability of filogenetic tree branches was analyzed using the bootstrap method (1000 iterations). Evolutionary divergence level between the sequences was evaluated using the MEGA v.6 software (Tamura et al., 2013).

Wolbachia contamination. Identification of the Wolbachia symbiotic bacteria was carried out using specific primers for bacterial surface protein gene $w s p(81 \mathrm{~F}$ and $691 \mathrm{R}$, see Braig et al., 1998). In order to separate the two strains, multiprimer PCR was used (Zhou et al., 1998): primers $383 \mathrm{~F}$ and $183 \mathrm{~F}$ were paired with wsp-691R to separate the $w \mathrm{AlbA}$ and $w \mathrm{AlbB}$ strains of Wolbachia in Ae. albopictus. The PCR fragment corresponding to the $w$ AlbA strain was one of $379 \mathrm{bp}$, and to the $w$ AlbB strain - of $501 \mathrm{bp}$. Validity evaluation for the received data on bacterial contamination in the samples was carried out using the Fischer accuracy test with the error margin set for $N>10$ (Tokarev et al., 2017).

Susceptibility to Dirofilaria. Only hemotrophic gonoactive female mosquitoes collected in the wild were used for analysis. In order to determine dirofilaria contamination in mosquito pools, the mosquito imagos were dissected, their abdomen and head-thorax parts separated, and 2 to 7 sample mosquitoes were grouped into pools based on their collection time and place. In the head-thorax parts, L3 larvae were registered. Contamination of mosquitoes with Dirofilaria larvae was revealed by the amplification of the ITS2 area using the DIDR-F1 and DIDR-R1 primers (Rishniw et al., 2006). PCR sequence size, specific

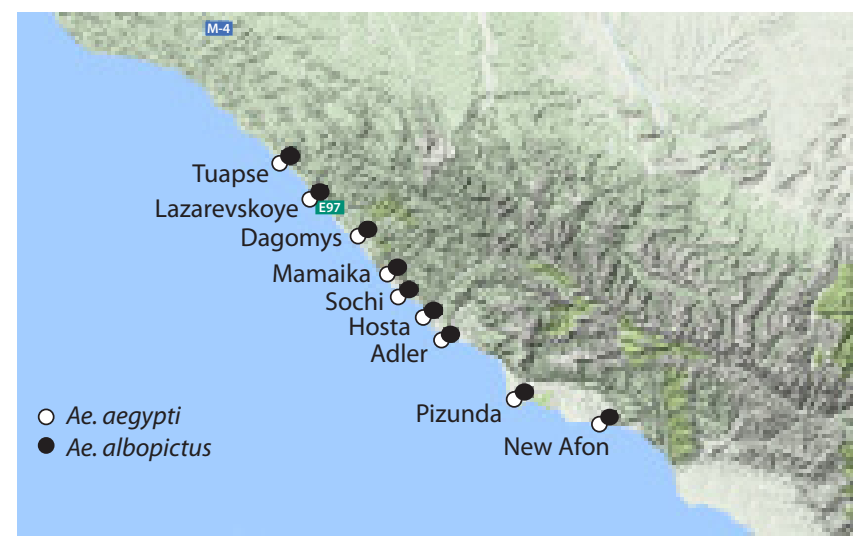

Fig. 1. Sampling points on the Caucasian coast of the Black Sea.

to D. immitis was $542 \mathrm{bp}$, for D. repens $-484 \mathrm{bp}$. For Dirofilaria DNA screening was conducted in pools and not individually, contamination was evaluated using the common MIR (minimum infection rate) method. The value was calculated based on the assumption that at least one mosquito specimen in the pool was infected with Dirofilaria with the minimum infection rate calculated as the number of positive pools divided by the total specimen quantity and expressed as a percentage (Cancrini et al., 2003).

\section{Results}

\section{Geography of sampling}

Mosquitoes Ae. aegypti and Ae. albopictus were collected on the coast of the Black Sea of Krasnodarskiy Region from Adler to Tuapse in years 2007, 2011-2013 and 2015-2017 (see Table 1). In 2012, the specimens of these species were additionally gathered in the Republic of Abkhazia near Pizunda and New Afon (see Fig. 1). In 2007 Ae. albopictus were absent in the region, while in four sampling sites from Adler to Tuapse Ae. aegypti were common (see Table 1). Starting 2011, Ae. albopictus were present in each pool from every populated area. Moreover, the quantity of collected Ae. albopictus was vastly superior to the one of Ae. aegypti in the area from Adler to Dagomys. In years 2012, 2013 and 2016 Ae. aegypti were not registered in Hosta and Dagomys. However, Ae. aegypti prevailed numerically in Tuapse, the northern part of the region, in years 2012 and 2013.

In year 2017 collection was conducted only in Sochi and Adler, and the larvae and imagos were attributed solely to Ae. albopictus. In the pools of adult mosquitoes no Ae. aegypti specimen was present, as no Ae. aegypti larvae were found in typical breeding grounds of this species (various small artificial basins filed with water: barrels, cans, decorative pools, old dishware, tires). A sample from a dried car tire found in Adler in August 2017 contained preserved viable eggs of Ae. aegypti and Ae. albopictus with the prevalence of Ae. aegypti, which later developed in the lab into larvae and imagos. 
Table 2. Variable sites in the ITS2 region of Ae. aegypti

\begin{tabular}{|c|c|c|c|c|c|c|c|c|c|c|c|c|c|c|c|}
\hline \multirow{4}{*}{$\begin{array}{l}\text { GenBank } \\
\text { annotation }\end{array}$} & \multirow[t]{4}{*}{ Origin } & \multicolumn{14}{|c|}{ Variable nucleotide sites* } \\
\hline & & 2 & 2 & 2 & 3 & 3 & 3 & 3 & 3 & 3 & 3 & 3 & 3 & 4 & 4 \\
\hline & & 5 & 5 & 5 & 4 & 5 & 5 & 5 & 5 & 5 & 5 & 5 & 5 & 9 & 9 \\
\hline & & 3 & 4 & 5 & 9 & 1 & 2 & 3 & 4 & 5 & 6 & 7 & 8 & 2 & 4 \\
\hline MH142327 & IMPITM & G & $\mathrm{T}$ & G & A & C & $\mathrm{T}$ & A & A & C & $\mathrm{T}$ & A & G & $\mathrm{T}$ & $\mathrm{T}$ \\
\hline MH142320 & Sochi, 2007 & . & . & . & . & . & .. & . & . & . & . & . & . & . & . \\
\hline MH142318 & Mamaika, 2012 & . & . & . & . & . & . & . & . & . & . & . & . & $\cdot$ & . \\
\hline MH142317 & Tuapse, 2012 & . & . & A & $0^{\circ}$ & . & . & . & . & . & . & . & . & . & $\theta^{\circ}$ \\
\hline MH142326 & Adler, 2017 & - & - & . & C & . & . & . & . & . & . & . & A & G & . \\
\hline MH142316 & New Afon, 2012 & - & - & . & 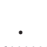 & - & - & - & - & - & - & - & - & . & C \\
\hline MH142319 & Adler, 2013 & - & - & . & & - & - & - & - & - & - & - & - & . & C \\
\hline
\end{tabular}

Note: * The nucleotide positions are indicated relative to the MH142327 sequence. In Tables 2 and 3, the points denote the nucleotides identical to those indicated in the first line, dashes - the absence of nucleotides in the sequence (deletions).

Table 3. Variable sites in the ITS2 region of Ae. albopictus

\begin{tabular}{|c|c|c|c|c|c|}
\hline \multirow[t]{4}{*}{$\begin{array}{l}\text { Gene Bank } \\
\text { annotation }\end{array}$} & \multirow[t]{4}{*}{ Origin } & \multicolumn{4}{|c|}{$\begin{array}{l}\text { Variable nucleotide } \\
\text { sites* }^{*}\end{array}$} \\
\hline & & 3 & 3 & 3 & 3 \\
\hline & & 0 & 3 & 6 & 6 \\
\hline & & 8 & 1 & 3 & 4 \\
\hline $\mathrm{MH} 142321$ & Hosta, 2011 & G & $\mathrm{T}$ & G & C \\
\hline MH142322 & Pizunda, 2012 & . & . & . & $\therefore$ \\
\hline MH142323 & Pizunda, 2012 & A & $\mathrm{C}$ & - & - \\
\hline MH142324 & Tuapse, 2013 & A & C & . & $\cdot$ \\
\hline MH142325 & Adler, 2017 & ${ }^{\circ}$ & C & . & . \\
\hline
\end{tabular}

* The nucleotide positions are indicated relative to the MH142321 sequence.

\section{PCR analysis}

Ae. aegypti lab line. The Ae. aegypti mosquito lab line has been constantly sustained for more than five decades in the laboratory of the Martsinovskiy institute. The line was named "IMPITM" after the abbreviated name of the institute. Parts of the COI gene were sequenced for two mosquitoes from two different genres. DNA sequences from all four specimens were identical, one sequence was registered in Gene Bank under number MH023409. Two variable sites $\mathrm{G} 148 \mathrm{~A}$ and $\mathrm{T} 624 \mathrm{a}$ (the site numbers correspond to $\mathrm{MH} 023409$ ) in $C O I$ separated IMPITM-line from lab cultures Ae. aegypti Liverpool (AY432648) and RED (AF390098). As a nuclear marker, ITS2 area from Ae. aegypti IMPITM (GenBank annotation MH142327) was sequenced. ITS2 DNA in Ae. aegypti IMPITM was identical to DNA of the Rockfeller strain (KF471588).

Nuclear DNA variability in Ae. aegypti and Ae. albopictus. In Ae. aegypti four haplotypes with different single-nucleotide substitutions and two deletions in their ITS2 areas were found (Table 2). The first type was Ae. aegypti collected in Sochi (2007) and Big Sochi - Mamaika (2012). The second type was from Tuapse (2012) and dif-
Table 4. Estimates of average evolutionary divergence over ITS2/COI sequence pairs between and within the studied Aedes

\begin{tabular}{|c|c|c|c|}
\hline Species & Ae. aegypti & Ae. albopictus & Ae. cretinus \\
\hline Ae. aegypti & $\begin{array}{l}0.005^{*} \\
0.0028^{*}\end{array}$ & & \\
\hline Ae. albopictus & $\begin{array}{l}0.14 \\
0.37\end{array}$ & $\begin{array}{l}0.004^{*} \\
0.0127^{*}\end{array}$ & \\
\hline Ae. cretinus & $\begin{array}{l}\text { n. d. } \\
0.30\end{array}$ & $\begin{array}{l}\text { n. d. } \\
0.38\end{array}$ & \\
\hline Ae. koreicus & $\begin{array}{l}\text { n. d. } \\
0.28\end{array}$ & $\begin{array}{l}\text { n. d. } \\
0.46\end{array}$ & $\begin{array}{l}\text { n. d. } \\
0.39\end{array}$ \\
\hline
\end{tabular}

Note: The number of base substitutions per site from averaging over all sequence pairs within and between the Aedes species is shown. Below the diagonal are differences in ITS2 sequences; above the diagonal - in $\mathrm{COI}$.

* Intraspecific differences; n. d. - not defined.

fered from the first by one G255A replacement. The third haplotype was discovered in the specimens from New Afon and Adler (2013). This haplotype differed by two deletions (two and eight nucleotides) and one T494C replacement. In the ITS2 area of Ae. aegypti collected in Adler (2017) two deleted nucleotides were found, which was similar to the first haplotype, and three nucleotide replacements - A349C, G358A and T492G.

Four variable haplotypes were found in Ae. albopictus, different by single-nucleotide mutations and one deletion (Table 3). The earliest in this respect is the Hosta collection (2011). We found an identical haplotype in Ae. albopictus from Pizunda (2012). The second similar haplotype was found in another specimen from the same collection (Pizunda, 2012), different by deletions of two nucleotides and replacements in G308A and T331C. The third haplotype of Ae. albopictus (Tuapse, 2013), unlike the second, had no deletion. The fourth one was found in Ae. albopictus (Adler, 2017) and had one T331C replacement.

Intraspecific ITS2 variability in wild Ae. aegypti was $0.3 \%$, while the variability in wild Ae. albopictus was $1.3 \%$ (Table 4). The genetic differences between species 


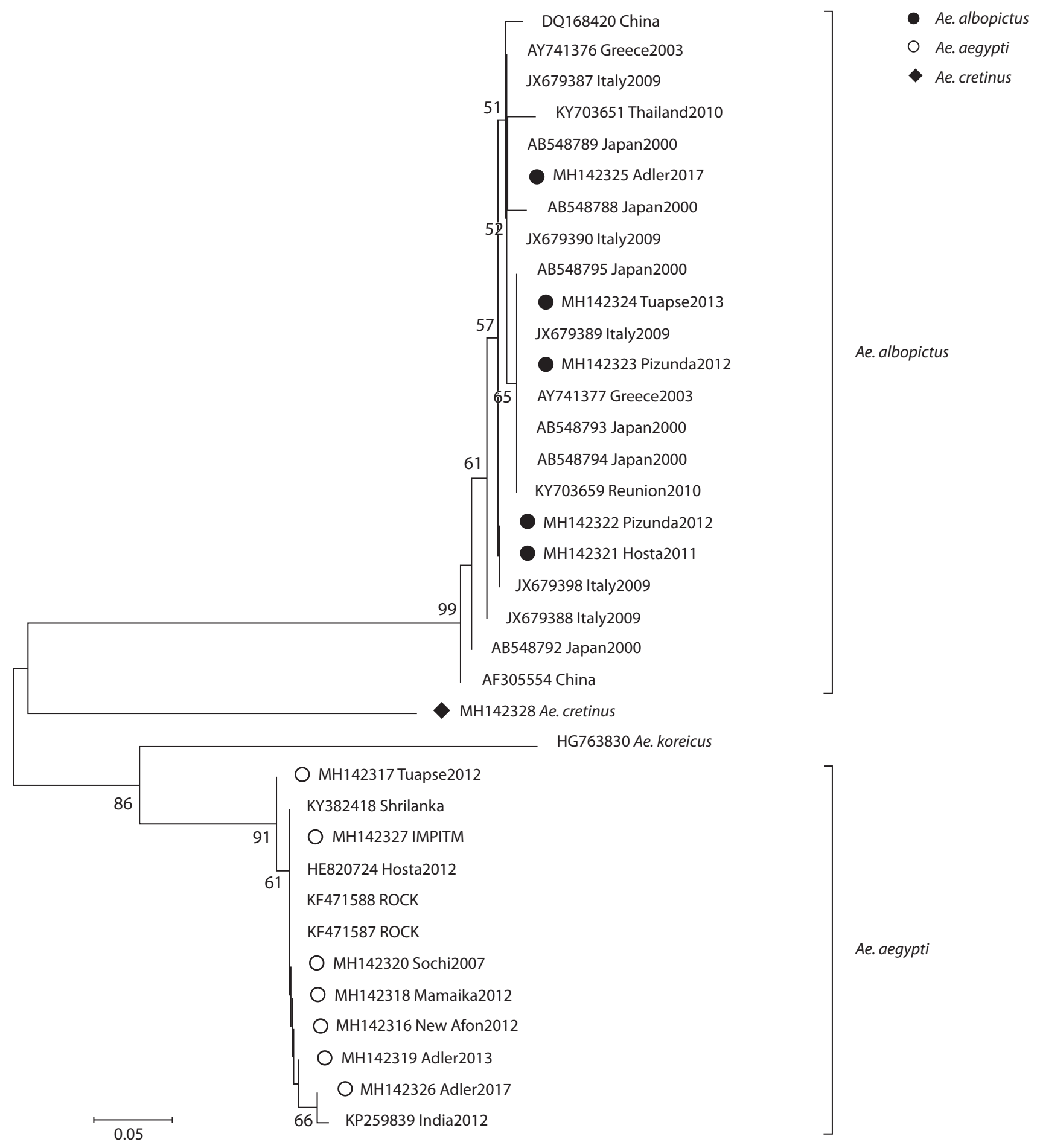

Fig. 2. Similarity dendrogram derived from comparative analysis of the ITS2 areas. All the deletions were excluded from the analysis. 


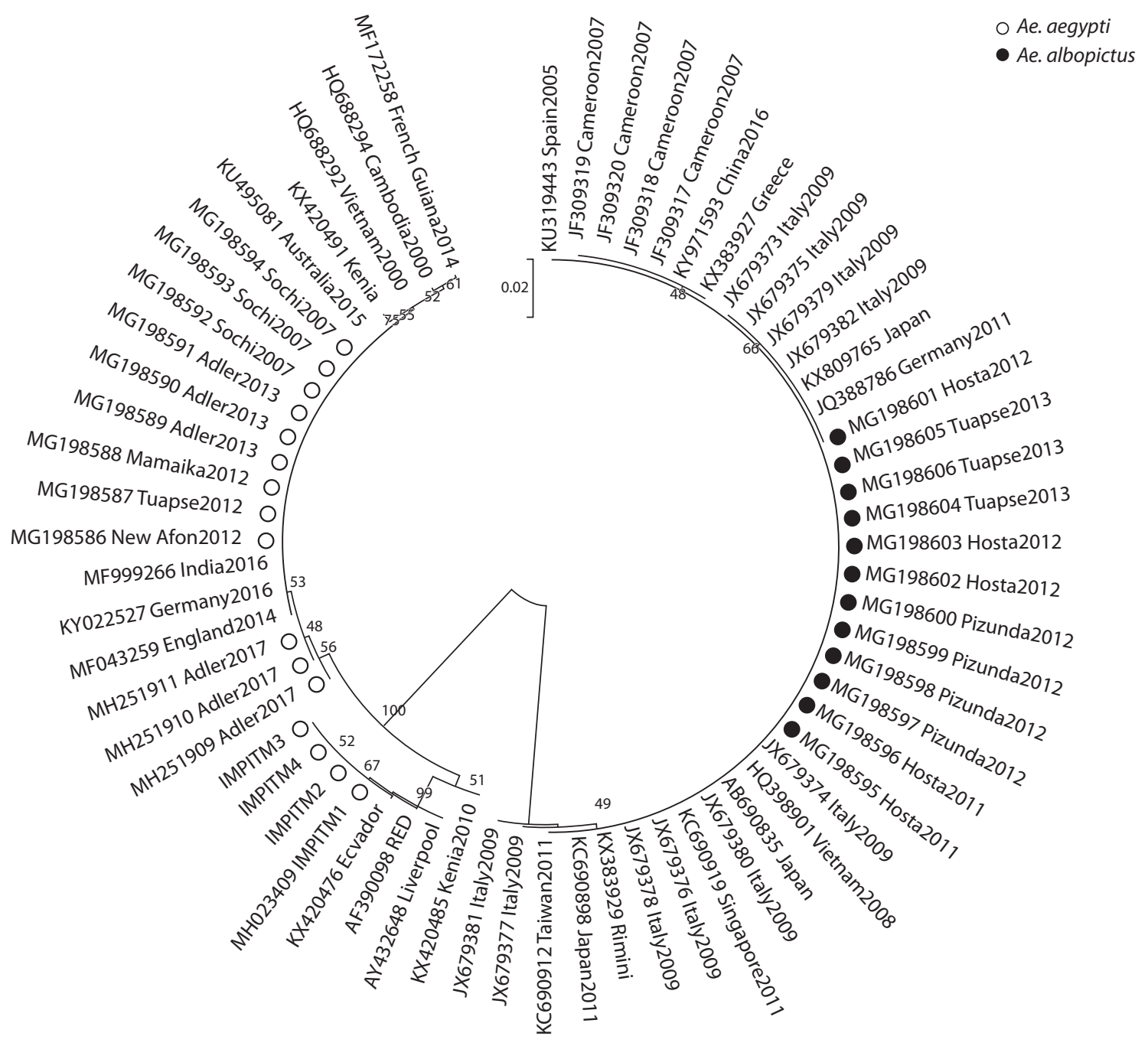

Fig. 3. Similarity dendrogram of the $\mathrm{CO}$ gene sequences in Ae. aegypti and Ae. albopictus.

after ITS2 comparison indicated that Ae. aegypti was 1.3 times closer to Ae. koreicus and Ae. cretinus than to Ae. albopictus (Table 4).

Comparison of the identified sequences between themselves and with their analogues from Gene Bank showed that, while the ITS2 region was variable in one mosquito species, its identical variants were present in specimens from geographically separated regions (Fig. 2). The ITS2 sequences of each species form different dendrogram clusters, their differences supported by the high values in bootstrap analyses.

Mitochondrial DNA variability in Ae. aegypti and Ae. albopictus. Nine COI sequences from wild Ae. aegypty (2007, 2011-2015) were identical. Same variant is present in Gene Bank - annotated Ae. aegypty from Cambodia (2000), India, England (2014), French Guyana (2014), Australia (2015), Germany (2016) (Fig. 3). Ae. aegypti (Adler, 2017) had two other different mitochondrial haplotypes (MH251909-MH251911) with synonymous nucleotide replacements C48T and additional T189C in MH251909. The genetic diversity between Ae. aegypti specimens from the Black sea coast for the $C O I$ gene was determined to be $0.5 \%$. The differences between the wild specimens and the lab line included 11 nucleotide substitutes, one of which (G148A) was non-synonymous (see Fig. 3).

Among Ae. albopictus species two mitochondrial haplotypes were found. The first one consisted of 11 identical sequences in the specimens (2011-2017) which were also registered in Ae. albopictus from Spain (2005), Italy (2009), China, Taiwan (2011), and Japan (2011) (see Fig. 3). The second mitochondrial haplotype that differed from the others by synonymic replacement $\mathrm{A} 79 \mathrm{G}$ was aslo found in one mosquito from Hosta (2012) (MG198601). The haplotype identical to second one (79G) had been previously discovered in Ae. albopictis from northern Italy (2009), Japan and Germany (2011). The COI gene variability among Ae. albopictus was $0.4 \%$ (see Table 4).

\section{Endosymbiotic bacteria Wolbachia}

The frequency of Wolbachia contamination was investigated in 411 specimens of Ae. albopictus, 50 specimens of Ae. aegypti, 4- of Ae. cretinus and 5-of Ae. koreicus. 
Table 5. Prevalence of $W A \mathrm{lbA}$ and $w A \mathrm{lbB}$ strains of Wolbachia in Ae. albopictus from different sampling sites

\begin{tabular}{|c|c|c|c|c|c|}
\hline $\begin{array}{l}\text { Sampling site, } \\
\text { year }\end{array}$ & $N$ & $w A l b A$ & wAlbB & $w A l b A+w A l b B$ & Infection \pm SD $(\%)^{*}$ \\
\hline Pizunda, 2012 & 16 & 0 & 10 & 4 & $87.5 \pm 8.3$ \\
\hline Adler, 2013 & 30 & 0 & 18 & 0 & $60 \pm 8.9$ \\
\hline Hosta, 2011 & 6 & 1 & 0 & 5 & 100 \\
\hline Hosta, 2012 & 3 & 0 & 0 & 1 & 33.3 \\
\hline Sochi, 2012 & 35 & 0 & 34 & 0 & $97.1 \pm 2.8$ \\
\hline Mamaika, 2012 & 63 & 0 & 51 & 12 & 100 \\
\hline Dagomys, 2012 & 27 & 0 & 24 & 3 & 100 \\
\hline Dagomys, 2016 & 190 & 1 & 22 & 8 & $16.3 \pm 2.7$ \\
\hline Lazarevskoye, 2012 & 30 & 0 & 24 & 6 & 100 \\
\hline Tuapse, 2013 & 11 & 2 & 1 & 7 & $90.9 \pm 8.7$ \\
\hline Total & 411 & 4 & 184 & 46 & 56.9 \\
\hline
\end{tabular}

* Standard deviation (SD) was considered for samples of more than 10 individuals.

Table 6. Infection of Ae. albopictus and Ae. aegypti with D. immitis and D. repens

\begin{tabular}{|c|c|c|c|c|c|c|c|}
\hline \multirow[t]{2}{*}{ Species } & \multirow{2}{*}{$\begin{array}{l}\text { Number } \\
\text { of specimens } \\
\text { (pools) }\end{array}$} & \multicolumn{3}{|c|}{$\begin{array}{l}\text { Number of pools, } \\
\text { infected with } D \text {. repens }\end{array}$} & \multicolumn{3}{|c|}{$\begin{array}{l}\text { Number of pools, } \\
\text { infected with D. immitis }\end{array}$} \\
\hline & & Head-thorax & Abdomen & $\mathrm{MIR}, \%$ & Head-thorax & Abdomen & $\mathrm{MIR}, \%$ \\
\hline Ae. albopictus & $366(74)$ & 1 & 0 & 0.3 & 0 & 5 & 1.4 \\
\hline Ae. aegypti & $21(4)$ & 1 & 0 & 4.8 & 0 & 0 & 0 \\
\hline
\end{tabular}

All screened Ae. aegypti, Ae. cretinus, Ae. koreicus were not infected with Wolbachia. In Ae. aibopictus symbiotic bacteria Wolbachia were found in all the pools, the percentage of infected insects varied between 16.3 and $100 \%$ (Table 5). On the Caucasus coast all possible variants of infected Ae. albopictus were found. Between 234 positive specimens 3 variants of infection were found: rare strain $w \operatorname{AlbA}(1.7 \%)$, common strain $w$ AlbB $(78.6 \%)$ and superinfection with both strains $w \mathrm{AlbA}$ and $w \operatorname{AlbB}(19.7 \%)$; 177 specimens were not infected. What is especially interesting is the Dagomys population where in 2016 only 31 $(16.3 \%)$ out of the 190 mosquitoes were tested positively for Wolbachia. The infection rate of the Dagomys Ae. albopictus in 2016 was statistically different from the grand total (Fisher test, $p<0.0001$ ). If the Dagomys 2016 pool were removed from analysis, the total contamination of Ae. albopictus would be $91.8 \%$.

The variations in total infected specimens in the pools can be explained by their small count, like in the Hosta case (2012) or, possibly, by the poor condition of bacterial DNA in the preserved mosquitoes. The low total of infected mosquitoes was mainly due to Dagomys (2016). In this case, 190 specimens were checked and considering good PCR results for other genes, poor DNA condition was hardly the reason. Most probably, the low rate of Wolbachia infection was consistent and the Ae. albopictus population requires further investigation (see Table 5).

\section{Dirofilaria contamination}

Using PCR with specific primers for the DNA of two species of Dirofilaria 74 pools (366 specimens) of Ae. albopictus, and 4 pools (21 specimens) of Ae. aegypti were investigated (Table 6). Among 74 pools of Ae. albopictus one was infected with $D$. epens (MIR $=0.3 \%$ ), five pools were infected with $D$. immitis (MIR $=1.4 \%$ ). Only one pool of Ae. aegypti out of four was infected with $D$. repens $(\mathrm{MIR}=4.8 \%)$. D. immitis was found only in the abdomen pools of Ae. albopictus. Infective larvae L3 of D. repens were found in pools of head-thorax parts of the both species (see Table 6).

\section{Discussion}

Stable, replenishing population of Ae. albopictus inhabits the territory of Krasnodarsky Region's Black Sea coast. Mosquitoes Ae. albopictus, first registered in 2011, have been expanding with the great speed presenting serious competition to Ae. aegypti.

Survey of the territory in years 2012-2013 showed presence in this area of consistent, replenishing populations of two dangerous mosquito species - Ae. aegypti and Ae. albopictus (Ganushkina et al., 2013). In 2012, the areas surrounding New Afon and Pizunda were additionlly investigated, with the same mosquito species discovered. In Russia Ae albopictus were found only recently, in 2011, but they actively, as it is common for invasive species in a 
new place, have taken their niche around the Big Sochi in the wet subtropical climate zone, pressing Ae. aegypti from Adler to Lazarevskoe. In typical semidry Mediterranean climate zone, Tuapse area, Ae. aegypti were predominant in 2011-2013, while the quantity of Ae. albopictus in this territory was negligible. Further to the north to Anapa, where semidry Mediterranean climate is also present, no mosquitoes of both species were found during July, September and October of 2013 (Ganushkina et al., 2013). In 2014-2015 the population of Ae. albopictus and Ae. aegypti on the Caucasus coast of the Black Sea developed in the way similar to the 2012-2013 trends (Ganushkina et al., 2016). In populated areas to the south of Tuapse, mainly Ae. albopictus were registered. In Tuapse Ae. aegypti were predominant (Ae. aegypti share $70 \%$, Ae. albopictus $30 \%$ ), however, the count of Ae. albopictus began to rise. No further advances of Ae. albopictus in 2012-2014 to the northwest of Jubga (57 km from Tuapse, the last locality, where Ae. albopictus were registered) were observed. However, as we had predicted (Ganushkina et al., 2014b). Ae. albopictus mosquitoes were able to expand in the northwest direction making it essential to investigate the Gelendjik area, where M.V. Zabshata (2016) had found this species in 2015.

Our collections from July and August 2016, as well as the data by Fedotova M.V. et al. (2017a, b) demonstrated that in Adler, Hosta and Sochi no Ae. aegypti had been found, and only Ae. albopictus had occupied the coast. However, during August 2017 in Adler the viable eggs of both Ae. aegypti and Ae. albopictus were found, which was confirmed by DNA tests. The Ae. aegypti eggs are able to withstand prolonged dehydration, but below-zero temperatures are lethal to them. Consequently, despite the drastic decrease in population, in positive conditions Ae. aegypti are able to regain abundance. The population decrease may be linked to the competition between Ae. aegypti and Ae. albopictus larvae for food resources and the fertility loss in Ae. aegypti due to possible interspecies copulation (Bargielowski et al., 2015; Carrasquilla, Lounibos, 2015). A major role in preserving the viability of diapausing eggs of Ae. aegypti may be attributed to winter temperatures. Theoretically, Ae. aegypti areal may correlate with the lowest rate of night temperature at ground surface (Tsai et al., 2018). Median borderline temperature of 13.8 degrees may play a critical role in limiting of Ae. aegypti expansion on the Caucasus Black Sea coast, where during some years it drops down from -3 to -13 centigrade.

Amplification of the ITS2 region enables for identification of Ae. albopictus, Ae. aegypti, Ae. aretinus and Ae. koreicus based on the size of the PCR product. This method can be used along with morphological criteria for the accurate species identification. Genetic divergence in the variable non-coding ITS2 area among Ae. albopictus, Ae. cretinus, Ae. koreicus and Ae. aegypti constitutes between 28 and $46 \%$. Ae. albopictus is genetically closer to Ae. cretinus and Ae. koreicus than to Ae. aegypti. The divergence between Ae. albopictus and Ae. aegypti is $37 \%$, and in the coding sequence of COI gene it reaches $14 \%$.
The methods of molecular genetics were first used to characterize the mosquitoes from the lab line of Ae. aegypti cultivated in a laboratory for more than 50 years. The origin of first mosquitoes of the IMPITM line is unknown. According to the nuclear marker, these mosquitoes are identical to the specimens in the Rockfeller line. The COI gene analysis has shown that mosquitoes from the Ae. aegypti IMPITM lab line contain DNA close to the one of African mosquitoes and the specimens from the Liverpool and RED lab lines. The databases contain neither $C O I$ sequences for the Rockfeller strain, nor ITS2 for Liverpool and RED. Therefore, no possibility exists to compare Ae. aegypti IMPITM with any of the known laboratory cultures of Ae. aegypti using the both markers. The origin of the laboratory strains of Ae. aegypti, bred in the laboratories of USA, England, France and other countries since 1940-1950s are often unknown (Kuno, 2010). The Ae. aegypti Rockfeller line originated from Cuba and the Ae. aegypti Liverpool line - possibly from West Africa (Kuno, 2010). The RED line heritage was undetermined, but we know that it is a variant of the Rex-D strain of Ae. aegypti (Costa-da-Silva et al., 2017).

Ae. aegypti originated from Africa, from where they expanded firstly to South and North Americas, and then towards Asia (Bennett et al., 2016). Ae. aegypti found on the Caucasus coast of the Black Sea have the COI gene identical to the one of invasive mosquitoes from Southeast Asia (India, Cambodia), America (French Guyana), Australia and single specimens carried to Europe (Kampen et al., 2016; Dallimore et al., 2017). These invasive Ae. aegypti are likely to have adaptive properties to subtropical and even moderate climates.

Southeast Asia is considered to be the place of Ae. albopictus origin, from where these mosquitoes expanded worldwide. Previous research of Ae. albopictus had shown a low level of diversity in mitochondrial DNA, but found differences in the $C O I$ gene between the populations that are present in countries with tropical or subtropical climate (Mousson et al., 2005; Patsoula et al., 2006; Kamgang et al., 2011; Zitko et al., 2011), where tropical populations carry 363C, and subtropical - 363T (relative to MG198595). No tropical COI gene haplotype was found on the Black Sea coast. One of the haplotypes found in Ae. albopictus during our research was typical to Ae. albopictus not only from Taiwan and Japan but also from Italy and Spain (see Fig. 3). The second haplotype found in Ae. albopictus from Hosta (2012) also presents in Ae. albopictus from Japan, Italy and Germany.

Investigation of Ae. albopictus and Ae. aegypti from the Black Sea coast using the markers of nuclear and mitochondrial DNA and comparison with existing databases has shown a low level of diversity among the mosquitoes of these species collected in various sites and at different times. It confirms that the worldwide expansion of invasive Ae. aegypti, and especially Ae. albopictus, has been happening very fast and no evolutionary changes have occurred so far. 
Our findings confirmed the absence of symbiotic bacteria Wolbachia in wild Ae. aegypti. Wolbachia was not found in the specimens of Ae. cretinus и Ae. koreicus, but wider screening is required to make conclusive statements regarding symbiont presence in these species. We have revealed the circulation of two Wolbachia strains, wAlbA and $w \mathrm{AlbB}$, in the Ae. albopictus population from the Caucasus Black Sea coast. The $w$ AlbB strain is prevalent in our findings, which is similar for Ae. albopictus from different regions worldwide (Calvitti et al., 2015). It is known that the infection rate in the Ae. albopictus species is close to $100 \%$. Our values are lower, compared to what has usually been registered in Ae. albopictus. In the Dagomys collection (2016) less than $16 \%$ of specimens were infected. An Ae. albopictus population totally free from Wolbachia was discovered in Vietnam in 2012 (Minard et al., 2017). Thorough investigation into Wolbachia infection and the genetic structure of Ae. albopictus should be continued in Dagomys using the markers of nuclear and mitochondrial DNA in order to determine the nature of infected and noninfected mosquitoes.

One of the goals of this study was revealing of invasive stages of microfilaria in Ae. albopictus and Ae. aegypti in order to determine their role as dirofilaria vectors. In Ae. albopictus total dirofilaria infestation with both species consisted of 6 infected pools out of 74 (MIR $=1.6 \%$ ). In Ae. aegypti one mosquito infected with $D$. repens was found in a pool of four (MIR $=4.8 \%$ ). Such high count should be attributed to low amount of Ae. aegypti specimens in the test. Discovery of $D$. repens DNA in the thorax part of mosquitoes points to microfilaria development at larvae stage L3 and that both Ae. albopictus and Ae. aegypti can infect humans or animals while sucking blood. Spread of dirofilariasis along the Black Sea coast is facilitated by optimal climate conditions for the development of infective agents, as well as intensive migration of people and dogs. Obligate carriers of $D$. repens and $D$. immitis are known to be carnivorous animals of feline and canine family. (Sergiev et al., 2014; Bogacheva et al., 2017). Southern Russia, due to its climate, is the region where consistent dirofilaria transmission has been taking place. In recent years, rising trend of dirofilariasis has been observed not only in animals, but also in humans (Ermakova et al., 2017; Kartashev et al., 2018). Considering the growth of invasive mosquito population (Aedes gene) on the Caucasus Black Sea coast, the presence of this suitable carriers may be the cause of dirofilariasis spreading.

\section{Acknowledgements}

The authors would like to thank two anonymous review-ers for their valuable advice. The research was supported by the Russian Foundation for Basic Research, grant No. 16-0400091.

\section{Conflict of interest}

The authors declare no conflict of interest.

\section{References}

Adhami J., Reiter P. Introduction and establishment of Aedes (Stegomyia) albopictus Skuse (Diptera: Culicidae) in Albania. J. Am. Mosq. Control Assoc. 1998;14(3):340-343.

Bargielowski I.E., Lounibos L.P., Shin D., Smartt C.T., Carrasquilla M.C., Henry A., Navarro J.C., Paupy C., Dennett J.A. Widespread evidence for interspecific mating between Aedes aegypti and Aedes albopictus (Diptera: Culicidae) in nature. Infect. Genet. Evol. 2015; 36:456-61. DOI 10.1016/j.meegid.2015.08.016.

Bennett K.L., Shija F., Linton Y.M., Misinzo G., Kaddumukasa M., Djouaka R., Anyaele O., Harris A., Irish S., Hlaing T., Prakash A., Lutwama J., Walton C. Historical environmental change in Africa drives divergence and admixture of Aedes aegypti mosquitoes: A precursor to successful worldwide colonization? Mol. Ecology. 2016;25:4337-4354. DOI 10.1111/mec.13762.

Bocková E., Rudolf I., Kočišová A., Betášová L., Venclíková K., Mendel J., Hubálek Z. Dirofilaria repens microfilariae in Aedes vexans mosquitoes in Slovakia. Parasitol. Res. 2013;112:34653470. DOI 10.1007/s00436-013-3526-9.

Bogacheva A.S., Shaikevich E.V., Rakova V.M., Ganushkina L.A. The fauna of bloodsucking mosquitoes in the Nizhny Novgorod Region, their infection with Dirofilaria and endosymbiotic bacteria. Meditsinskaya Parazitologiya i Parazitarnye Bolezni = Medical Parasitology and Parasitical Disease. 2017;1:43-47. (in Russian)

Bourtzis K., Dobson S.L., Xi Z., Rasgon J.L., Calvitti M., Moreira L.A., Baton L.A., Hughes G.L., Mavingui P., Gilles J.R. Harnessing mosquito-Wolbachia symbiosis for vector and disease control. Acta Trop. 2014;132:150-163. DOI 10.1016/j.actatropica.2013.11.004.

Braig H.R., Zhou W., Dobson S.L., O’Neill S.L. Cloning and characterization of a gene encoding the major surface protein of the bacterial endosymbiont Wolbachia pipientis. J. Bacteriol. 1998; 180:2373-2378.

Calba C., Guerbois-Galla M., Franke F., Jeannin C., Auzet-Caillaud M., Grard G., Pigaglio L., Decoppet A., Weicherding J., Savaill M.C., Munoz-Riviero M., Chaud P., Cadiou B., Ramalli L., Fournier P., Noël H., De Lamballerie X., Paty M.C., Leparc-Goffart I. Preliminary report of an autochthonous chikungunya outbreak in France, July to September 2017. Euro Surveill. 2017;22(39):17-00647. DOI 10.2807/1560-7917. ES.2017.22.39.17-00647.

Calvitti M., Marini F., Desiderio A., Puggioli A., Moretti R. Wolbachia density and cytoplasmic incompatibility in Aedes albopictus: Concerns with using artificial Wolbachia infection as a vector suppression tool. PLoS One. 2015;10(3):e0121813. DOI 10.1371/journal.pone.0121813.

Cancrini G., Frangipane di Regalbono A., Ricci I., Tessarin C., Gabrielli S., Pietrobelli M. Aedes albopictus is a natural vector of Dirofilaria immitis in Italy. Vet. Parasitol. 2003;118(3-4):195202.

Carrasquilla M.C., Lounibos L.P. Satyrization without evidence of successful insemination from interspecific mating between invasive mosquitoes. Biol. Lett. 2015;11(9):20150527. DOI 10.1098/rsbl. 2015.0527.

Chuchuy A., Rodriguero M.S., Ferrari W., Ciota A.T., Kramer L.D., Micieli M.V. Biological characterization of Aedes albopictus (Diptera: Culicidae) in Argentina: implications for arbovirus transmission. Sci. Rep. 2018;8(1):5041. DOI 10.1038/s41598018-23401-7.

Costa-da-Silva A.L., Ioshino R.S., Araújo H.R., Kojin B.B., Zanotto P.M., Oliveira D.B., Melo S.R., Durigon E.L., Capurro M.L. 
Laboratory strains of Aedes aegypti are competent to Brazilian Zika virus. PLoS One. 2017;12(3):e0174081. DOI 10.1371/journal.pone. 0174081.

Dallimore T., Hunter T., Harbach R.E., Medlock J.M., Strode C., Vaux A.G. Discovery of a single male Aedes aegypti (L.) in Merseyside, England. Parasit. Vectors. 2017;10:309. DOI 10.1186/ s13071-017-2251-0.

Delatte H., Paupy C., Dehecq J.S., Thiria J., Failloux A.B., Fontenille D. Aedes albopictus, vector of chikungunya and dengue viruses in Reunion Island: biology and control. Parasite. 2008;15(1):3-13. DOI 10.1051/parasite/2008151003.

Delisle E., Rousseau C., Broche B., Leparc-Goffart I., L'Ambert G., Cochet A., Prat C., Foulongne V., Ferre J.B., Catelinois O., Flusin O., Tchernonog E., Moussion I.E., Wiegandt A., Septfons A., Mendy A., Moyano M.B., Laporte L., Maurel J., Jourdain F., Reynes J., Paty M.C., Golliot F. Chikungunya outbreak in Montpellier, France, September to October 2014. Euro Surveill. 2015;20(17):pii=21108. DOI 10.2807/1560-7917. ES2015.20.17.21108.

Ermakova L.A., Tverdokhlebova T.I., Nagorny S.A., Pshenichnaya N.Yu., Boltachiev K.Kh. Analysis of incidence of larvae helminthiases (Echinococcosis, Toxocariasis, Dirofilariasis) in humans in the Russian Federation. Epidemiologiya i Vaktsynoprofilaktika $=$ Epidemiology and Vaccinoprophylaxis. 2017;16(1):43-46. (in Russian)

Fedorova M.V., Ryabova T.E., Shaposhnikova L.I., Lopatina Yu.V., Sebentzova A.N., Yunicheva Yu.V. Invasive mosquito species in Sochi: larval development sites and counting methods. Meditsinskaya Parazitologiya i Parazitarnye Bolezni = Medical Parasitology and Parasitical Disease. 2017a;4:9-15. (in Russian)

Fedorova M.V., Shvez O.G., Yunicheva Yu.V., Ryabova T.E., Medyanik I.M. Spreading of invasive mosquitoes Aedes (Stegomyia) aegypti (L., 1762) and Aedes (Stegomyia) albopictus (Skuse, 1895) (Diptera, Culicidae) in the southern Krasnodar region, Russia. Proc. of the II Symposium "Modern problems of general and special parasitology". St. Petersburg, 2017b;268-271. (in Russian)

Ganushkina L.A., Bezzhonova O.V., Patraman I.V., Tanygina E., Sergiev V.P. Distribution of Aedes (Stegomyia) aegypti L. and Aedes (Stegomyia) albopictus Skuse mosquitoes on the Black Sea coast of the Caucasus. Meditsinskaya Parazitologiya i Parazitarnye Bolezni $=$ Medical Parasitology and Parasitical Disease . 2013;1:45-46. (in Russian)

Ganushkina L.A., Morozova L.F., Patraman I.V., Sergiev V.P. Assessment of the risk of expansion of the habitats of the mosquitoes Aedes aegypti L. and Aedes albopictus Skuse in Russia. Meditsinskaya Parazitologiya i Parazitarnye Bolezni = Medical Parasitology and Parasitical Disease. 2014b;4:8-10. (in Russian)

Ganushkina L.A., Patraman I.V., Rezza G., Migliorini L., Litvinov S.K., Sergiev V.P. Detection of Aedes aegypti, Aedes albopictus, and Aedes koreicus in the area of Sochi, Russia. Vector-Borne Zoonotic Dis. 2016;16(1):58-60. DOI 10.1089/ vbz.2014.1761

Ganushkina L.A., Rakova V.M., Ivanova I.B., Supryaga V.G., Sergiev V.P. Entomological monitoring of an area to assess Dirofilaria transmission risk. Meditsinskaya Parazitologiya i Parazitarnye Bolezni $=$ Medical Parasitology and Parasitical Disease. 2014a;3:9-12. (in Russian)

Ganushkina L.A., Tanygina E., Bezzhonova O.V., Sergiev V.P. Detection of Aedes (Stegomyia) albopictus Skuse mosquitoes in the Russian Federation. Meditsinskaya Parazitologiya i Parazitarnye Bolezni $=$ Medical Parasitology and Parasitical Disease. 2012;1:3-4. (in Russian)
Gutsevich A.V., Monchadskiy A.S., Shtakelberg A.A. Fauna of the USSR: Diptera. Mosquitoes. Vol. III, Iss. 4. Leningrad: Nauka Publ., 1970. (in Russian)

Jeffries C.L., Walker T. Wolbachia biocontrol strategies for arboviral diseases and the potential influence of resident Wolbachia strains in mosquitoes. Curr. Trop. Med. Rep. 2016;3:20-25. DOI 10.1007/s40475-016-0066-2.

Kamgang B., Brengues C., Fontenille D., Njiokou F., Simard F., Paupy C. Genetic structure of the tiger mosquito, Aedes albopictus, in Cameroon (Central Africa). PLoS One. 2011;6(5):e20257. DOI 10.1371/journal.pone.0020257.

Kampen H., Jansen S., Schmidt-Chanasit J., Walther D. Indoor development of Aedes aegypti in Germany, 2016. Euro Surveill. 2016; 21(47):30407. DOI 10.2807/1560-7917.ES.2016.21.47.30407.

Kartashev V., Sagach O., Nikolaenko S., Chizh N., Korzan A., Ambalov Y., Bastrikov N., Ilyasov B., González-Miguel J., Morchón G., Siles-Lucas M., Simon F. Emerging Human dirofilariasis as a medical problem. Proc. of 28th Annual Meeting of the German Society for Parasitology. Berlin, 21-24 March. 2018;161.

Kronefeld M., Kampen H., Sassnau R., Werner D. Molecular evidence for the occurrence of Dirofilaria immitis, Dirofilaria repens and Setaria tundra in mosquitoes from Germany. Parasit. Vectors. 2014;7:30. DOI 10.1186/1756-3305-7-30.

Kuno G. Early history of laboratory breeding of Aedes aegypti (Diptera: Culicidae) focusing on the origins and use of selected strains. J. Med. Entomol. 2010;47:957-971. DOI 10.1603/ ME10152.

Marzinovsky E.I. Measures against dengue fever in Russia. Russian Journal of Tropical Medicine, Medical and Veterinary Parazitology. 1929;7(3):162-165. (in Russian)

Medlock J.M., Hansford K.M., Versteirt V., Cull B., Kampen H., Fontenille D., Hendrickx G., Zeller H., Van Bortel W., Schaffner F. An entomological review of invasive mosquitoes in $\mathrm{Eu}-$ rope. Bull. Entomol. Res. 2015;105(6):637-663. DOI 10.1017/ S0007485315000103.

Minard G., Van V.T., Tran F.H., Melaun C., Klimpel S., Koch L.K., Ly Huynh Kim K., Huynh Thi Thuy T., Tran Ngoc H., Potier P., Mavingui P., Valiente Moro C. Identification of sympatric cryptic species of Aedes albopictus subgroup in Vietnam: new perspectives in phylosymbiosis of insect vector. Parasit. Vectors, 2017;10(1):276. DOI 10.1186/s13071-017-2202-9.

Mousson L., Dauga C., Garrigues T., Schaffner F., Vazeille M., Failloux A.-B. Phylogeography of Aedes (Stegomyia) aegypti (L.) and Aedes (Stegomyia) albopictus (Skuse) (Diptera: Culicidae) based on mitochondrial DNA variations. Genet. Res., Camb. 2005;86(1):1-11. DOI 10.1017/S0016672305007627.

Patsoula E., Samanidou-Voyadjoglou A., Spanakos G., Kremastinou J., Nasioulas G., Vakalis N.C. Molecular and morphological characterization of Aedes albopictus in northwestern Greece and differentiation from Aedes cretinus and Aedes aegypti. J. Med. Entomol. 2006; 43(1):40-54.

Porter C.H., Collins F.H. Species-diagnostic differences inaribosomal DNA internal transcribed spacer from the sibling species Anopheles freeborni and Anopheles hermsi (Diptera: Culicidae). Am. J. Trop. Med. Hyg. 1991;45:271-279.

Riabova T.E., Yunicheva I.V., Markovich N.I., Ganushkina L.A., Orabey V.G., Sergiev V.P. Detection of Aedes (Stegomyia) aegypti L. mosquitoes in Sochi City. Meditsinskaya Parazitologiya i Parazitarnye Bolezni $=$ Medical Parasitology and Parasitical Disease. 2005;3:3-5 (in Russian)

Rishniw M., Barr S.C., Simpson K.W., Frongillo M.F., Franz M., Alpizar J.L. Discrimination between six species of canine mi- 
crofilariae by a single polymerase chain reaction. Vet. Parasitol. 2006;135:303-314. DOI 10.1016/j.vetpar.2005.10.013.

Sergiev V.P., Supriaga V.G., Bronshtein A.M., Ganushkina L.A., Rakova V.M., Morozov E.N., Fedianina L.V., Frolova A.A., Morozova L.F., Ivanova I.B., Darchenkova N.N., Zhukova L.A. Results of studies of human dirofilariasis in Russia. Meditsinskaya Parazitologiya i Parazitarnye Bolezni = Medical Parasitology and Parasitical Disease. 2014;3:3-9. (in Russian)

Shaikevich E.V. PCR-RFLP of the COI gene reliably differentiates $C x$. pipiens, Cx. pipiens form molestus and Cx. torrentium of the Pipiens Complex. Eur. Mosq. Bull. 2007;23:25-30.

Simon C., Frati F., Beckenbach A., Crespi B., Liu H., Flook P. Evolution, weighting, and phylogenetic utility of mitochondrial gene sequences and a compilation of conserved polymerase chain reaction primers. Ann. Entomol. Soc. Am. 1994;87(6):651-701.

Tamura K., Stecher G., Peterson D., Filipski A., Kumar S. MEGA6: Molecular Evolutionary Genetics Analysis version 6.0. Mol. Biol. Evol. 2013;30:2725-2729. DOI 10.1093/molbev/mst197.

Tokarev Y., Yudina M., Malysh J., Bykov R., Frolov A., Grushevaya I., Ilinsky Y. Prevalence rates of the Wolbachia endosymbiotic bacterium in natural populations of Ostrinia nubilalis and Ostrinia scapulalis (Lepidoptera: Pyraloidea: Crambidae) in South-Western Russia. Ekologicheskaya Genetika = Ecological
Genetics (St. Petersburg). 2017;15(1):44-49. DOI 10.17816/ecogen15144-49. (in Russian)

Tsai P.-J., Lin T.-H., Teng H.-J., Yeh H.-C. Critical low temperature for the survival of Aedes aegypti in Taiwan. Parasit. Vectors. 2018; 11(1):22. DOI 10.1186/s13071-017-2606-6.

Yunicheva I.V., Ryabova T.E., Markovich N.I., Bezzhonova O.V., Ganushkina L.A., Semenov V.B., Tarkhov G.A., Vasilenko L.E., Guzeeva T.M., Sergiev V.P. First evidence for Aedes aegypti L. propagation in Greater Sochi and in some towns of Abkhasia. Meditsinskaya Parazitologiya i Parazitarnye Bolezni = Medical Parasitology and Parasitical Disease. 2008;3:40-43. (in Russian) Zabashta M.V. The expansion of Aedes (Stegomia) albopictus Skuse, 1885 on the Black Sea coast of Russia. Meditsinskaya Parazitologiya i Parazitarnye Bolezni = Medical Parasitology and Parasitical Disease. 2016;3:10-11. (in Russian)

Zhou W., Rousset F., O’Neil S. Phylogeny and PCR-based classification of Wolbachia strains using wsp gene sequences. Proc. R. Soc. B. 1998;265(1395):509-515.

Zitko T., Kovacic A., Desdevises Y., Puizina J. Genetic variation in East-Adriatic populations of the Asian tiger mosquito, Aedes albopictus (Diptera: Culicidae), inferred from NADH5 and COI sequence variability. Eur. J. Entomol. 2011;108(4):501-508. DOI 10.14411/eje.2011.065. 